\title{
Proverbs and stylistic devices of Akwasi Ampofo Agyei's Akan highlife lyrics
}

Kofi Agyekum

Professor

School of Performing Arts

University of Ghana, Legon

Joshua Amuah

Senior Lecturer

School of Performing Arts

University of Ghana, Legon

Adwoa Arhine

Lecturer

School of Performing Arts

University of Ghana, Legon

Corresponding author's e-mail: KAgyekum@ug.edu.gh

Submitted: July 20, 2020 / Accepted: November 18, 2020 / Published: December 30, 2020

\begin{abstract}
This paper examines the stylistic features and proverbs in oba nyansafo wobu no be na wonka no asem, 'A wise child is spoken to in proverbs' a popular Ghanaian highlife song by the late Akwasi Ampofo Agyei. This is an area which is still grey in the study of highlife music. The paper basically adopted qualitative methodology through interviews and recordings. The paper combines the theories of language ideology and ethnomusicology, and looks at the indispensable, didactic and communicative functions of stylistic devices and proverbs in Akan highlife. These tropes as forms of indirection help the musicians to comment on very delicate issues. They depict the musician's communicative competence in the Akan language, cultural beliefs, worldview and social structures. The paper further reflects on the relative absence of proverbs in current Ghanaian highlife. The stylistic devices and proverbs in the song are subjected to ethnomusicological, stylistic and pragmatic analysis.
\end{abstract}

Key words: Language ideology, ethnomusicology, stylistic devices, proverbs Legon Journal of the Humanities 31.1 (2020) Page $\mid 117$ 


\section{Introduction: Brief notes on highlife}

This paper looks at proverbs in highlife one of the musical genres of Ghana. Highlife musical traditions evolved along the coastal areas in Ghana as a result of interaction with Gru sailors. Scholars such as John Collins (2006) and AmoahRamey (2018) among others have done extensive work on the history of Ghanaian highlife music.

A characteristic feature of highlife music is the fusion of indigenous and western musical elements largely drawn from the folk music traditions (Collins, 1989). For instance, palm wine highlife music is exemplified by a fusion of osibisaaba, odonson, etc. and the guitar tradition (Collins, 2006). Many of the elements of the creative processes in palm wine highlife music were thus, grounded in the folk music tradition.

There are studies on proverbs in highlife songs by scholars like Agyekum (2005a, 2016) and Yankah (1997). Some previous papers have looked at Alex Konadu and Nana Ampadu and their use of multiple proverbs in highlife song text and how they have been cleverly crafted in their composition of songs (see Agyekum 2005a, Agyekum 2016, and Yankah, 1997). So far there appears to be no studies on Akwasi Ampofo Agyei - a reputable highlife artiste, who is versatile in the use of proverbs, hence this paper. In this paper, we examine proverbs and other stylistic devices used by Ampofo Agyei in his song sba nyansafo wobu no be na wonka no asem (A wise child is spoken to in proverbs). The song's phrases and the constitutive proverbs have an intrinsic dialogical quality and reflect a deep sense of Akan musical expression. The paper discusses the Akan worldview of proverbs as a mark of one's "communicative competence in indigenous Akan communication" (see Agyekum, 2012).

\section{Language ideology}

This paper investigates the highlife music from the perspective of language ideology (LI) and ethnomusicology. We argue that one can have a better understanding of the use 
of proverbs in music especially highlife, if one understands the ideology of the people. Ideologies are shared and predictable beliefs and ideas of a people that are noted to be real and implicit in their everyday life situations within a period of time (see Agyekum, 2016, 2010). Silverstein (1998, p. 123) avers that "Language ideologies are sets of beliefs about language articulated by users as a rationalization or justification of perceived language structure and use." (See Verschueren, 1999, p. 198). Language use and its interpretation are based on the linguistic ideology of the group. Speakers' awareness about the structure and nature of their language, affects their social and rational behaviour including the use of appropriate language in their music.

Irvine (1989, p. 255) postulates that 'Language ideologies are the cultural systems of ideas about social and linguistic relationship, together with their loading of moral and political interests'. Rumsey (1990, p. 346) opines that, "linguistic ideologies are "shared bodies of common-sense notions about the nature of language in the world." Since the beliefs are shared, they are predictable during its application.

Language ideology provides a sociocultural understanding and interpretation of the political, cultural, economic, law, religious processes, music, and people's way of life that inform the local beliefs about language and culture. It effectively coordinates language, and facets of culture including institutional power, identity, status, gender, language policies, concepts, perceptions, worldview, people's intellect, psychological behaviour and their entire sociocultural world (see Agyekum, 2016, 2010; Fairclough, 1989; Kroskrity, 2006; Silverstein, 1998, p. 126).

Irvine and Gal (2000, p. 35) posit that LI refers to "the ideas with which participants and observers frame their understanding of linguistic varieties and map those understandings onto people, events, and activities that are significant to them." In this view, participants in the linguistic environment and performances are 
at the center of LI. We can argue that the lyrics of Ampofo Agyei were influenced by his knowledge of the Akan language, culture and cultural ideology.

\section{Ethnomusicology and Akan folksongs}

Ethnomusicology provides one of the avenues by which one can understand the language, culture and the behaviour of people through their music. To understand people's music you need some level of knowledge of their language and culture. The Society of Ethnomusicology (SEM) conceptualizes ethnomusicology as a reading of music in its "social and cultural context" acknowledging that in order to understand music holistically and not only what it is but also what it means to its practitioners and audience, ethnomusicologists examine it as a social process (see https://www.ethnomusicology.org/page/ AboutEthnomusicol).

In essence, ethnomusicology goes beyond the musicological analysis of the form, description, and structure of the sonic sound to study the music of a people from an anthropological standpoint that encompasses their culture (see Agyekum et al, 2019).

Notwithstanding these descriptions, debates on the definition of ethnomusicology continue as practitioners of the field seek to provide a clearer definition of it. Nettl (2005, pp. 12-13) identifies four key elements that contextualize the field. He suggests that ethnomusicology is the study of; (i) music in culture, (ii) the world's music from a comparative and relativistic perspective, (iii) [with] the use of fieldwork, (iv) all the musical manifestations of a society. His descriptions foreground the multidisciplinary nature of the field. In relation to this contextualization, items (i) and (ii) are relevant to this paper. To understand how proverbs have been employed in highlife, it is essential to understand its socio-cultural milieu. Although highlife music has been described in numerous contexts as a musical genre that resonates with many ethnic groupings, the most 
popular traditional group that engages in highlife performances are the Akan people (Nketia, 1959, 1964; Collins, 1989). What characterises the Akan highlife performance practice is how the composers incorporate aspects of their folklore in their creative processes.

Among the Akan of Ghana, the socio-cultural and political milieu of folksongs has been highlighted by a renowned Ghanaian ethnomusicologist, Prof J.H.K Nketia. Nketia (1957) observed how musical forms were organized to meet the needs of people's social lives. There were musical types which were set aside for recreation and daily lives as well as those for various ceremonial occasions. He noted that the repertoire of folksongs often makes references to the people's historical events and social genealogy.

Nketia (1957) further noted that these folk music traditions in the country experienced some form of transformation with the appearance of new musical styles. What is striking in Nketia's paper is the attribution of highlife music as a new form of folk music. This is premised on the grounds that the emergence of highlife music was characterized by its popularity and its emergence as a lingua-franca for many people.

Agyekum et al (2019) studied the political role of music in Ghana and discussed issues like motivation, struggle for independence, patriotism and agitation. In ethnomusicology, researchers approach music as a social phenomenon, by investigating and analysing it within an ethnographical framework that considers the language and culture of the people as the strong and reliable pillar.

Renowned oral literature scholars like Finnegan and Okpewho emphasised folksongs in some of their works that were often grounded within an interdisciplinary framework. They discussed types of songs from anthropological and political standpoints. In this respect, Finnegan states that

This indirect means of communicating with 
someone in power through the artistic medium of a song is a way by which the singers hope to influence while at the same time avoiding the open danger of speaking directly. The conventionality of the song makes it possible to indicate publicly what could not be said privately or directly to a man's face (Finnegan, 2012, p. 268).

Finnegan's premise on the indirect means of communication in music highlights the framework within which composers of folksongs work by employing certain literary devices to communicate effectively. One such device often used by these musicians is proverbs. Among the Akan of Ghana, the complex public space needs good orators.

Highlife musicians who often enter such public spaces via their composition are often conscious of this requirement. It is incumbent upon the composer to conduct research on the people they serve. It is thus appropriate to situate folk music artistes within the ethnomusicological trope as their creative process often resonate with the methodological approach of the field. Although not formally trained in western music, their approach to music is in sync with the traditional approaches because they are a part of them. They employ their socio-cultural understanding and knowledge of the people's language and culture in creating their works. The premise of this paper is foregrounded on the use of Akan proverbs as a stylistic device in highlife song texts. Other renowned highlife artistes like Konadu, Nana Ampadu, Akwaboa, Opambour, Okukuseku, Kaikaiku, and Dr. K. Gyasi intersperse their song texts with many proverbs.

\section{Methodology}

The methodology was basically qualitative through interviews and recordings. The subject of our inquiry - the musician Ampofo Agyei - is deceased so we relied on a broadcaster who specializes in the study of the life and works 
of Ghanaian highlife artistes, both the dead and the living. The broadcaster is a popular DJ called Roman Father. He hosts a programme called Adadamu on Atinka FM, a local station in Accra. His programme is aired on Saturdays from $11 \mathrm{am}-2.00 \mathrm{pm}$. We interviewed him in January 2020. We also interviewed Mr. Daniel Amponsah (alias, Agya Koo Nimo who is a folksong composer) together with Akan broadcasters and experts in Akan language and culture. These were Bosie Amponsah, formerly of GBC 1, Mr Baning Peprah, a retired teacher, the late Nana Agyei Sikapa of Peace FM, and the late Mr Apenteng Sackey a retired Akan lecturer of the Department of Linguistics, Legon.

Akwasi Ampofo Agyei's song was dubbed from YouTube. The entire song was transcribed and then translated from the Akan language into English. Each line was played several times to ensure accuracy and to check the authenticity of the transcription. Thereafter, the stylistic devices and proverbs were analysed at the ethnomusicological and linguistic levels.

\section{Biography of Akwasi Ampofo Agyei}

Ampofo Agyei was born in 1947. He was initially trained as a teacher, but he later abandoned the teaching profession and entered into the music industry and recorded his first album titled 'Obiara mfa n'adwene mmra', 'let us put our heads together'. Ampofo Agyei was greatly influenced by his parents and choral groups like 'Soul Believers' and Rainbow beats'. That set the pace for his musical career. When the two choral groups were dissolved, he constituted his own band, Kum Apem Royals. Ampofo Agyei was blessed with an inborn gift of proverbial lyrical capability and a great sense of innovation in music.

He won a number of awards including the Leisure Award, with his band voted Band of the Year 1999. Later, he was later among ten selected bands awarded with a citation by the National Commission on Culture. His song 'Woteetee me mfa to ha' was voted the best Highlife Song in the year 1985.

In the 1980s, Isaac Taylor who was the Chief Executive 
Officer of Roots Music Production and one of the top music producers in Ghana, assisted him to become a renowned musician. Ampofo Agyei undertook tours to Germany, Holland, France, United Kingdom, Ivory Coast, Togo, Liberia, Nigeria and many other countries. Outstanding musicians such as Abrantes Amakye Dede, Daddy Lumba, and K.K. Kabobo received training from him. He has many popular albums to his credit. Akwasi Ampofo Agyei died at the Komfo Anokye Teaching Hospital in Kumasi on August 2, 2004 after a short illness.

\section{Stylistic devices}

Stylistic qualities involve the ways in which the words and linguistic elements of an oral literature text are organized to ensure the effectiveness of the oral performance. Stylistic qualities deal with the style and the techniques of presentation that enhance oral literature art form. They are generally employed to enrich the work of the oral artiste and to make the audience enjoy the presentation (see Agyekum, 2013; Cuddon, 2013; Leech, 1969; and Wales, 2014).

Stylisticians have engaged with a wide variety of texttypes, yet the most popular object of study for stylistics is literature. The primary concern of this paper is to explore how stylistics can be employed to embellish literary works such as highlife songs (Busse \& McIntyre, 2010: 6). According to Blum (1992, pp. 178-179; pp. 202-203), early studies on music and style that centred on Euro-Western cultures, focused mainly on sound. Other studies on style that relate to African cultures have focused on beats spaced regularly in time (Waterman, 1984, cit. in Blum, 1992). All these, according to Blum, have limitations that are spelt out by scholars such as Chernoff (1979, pp. 91-152), Blacking (1995, pp. 10-12) and Coplan (1985). They revealed that style is not only about rhythm and rhetoric but includes "culturally defined principles that govern the operation of style such as, the contextual correlates of sound in different contexts". Style is further extended to cover the distinct expressive ways of 
performance, which usually serve as trademarks for identifying a musician, a poet or an ensemble (Nketia, 2005, p. 83)

The study of the synergy between music and linguistics is a task for both ethnomusicologists and linguists (Merriam, 1964, p. 187). Bright (1963, p. 27) comments that since patterns of language involving elements such as pitch, rhythm, etc., are among the essential elements of music, it is a reasonable hypothesis that features of spoken languages play a part in conditioning the musical patterns of a song. Agawu (2016, p. 136) thus emphasises that "no song is conceivable without language. Adopting a "musico-linguistic" approach, this paper explores elements of style in Akwasi Ampofo Agyei's performance of highlife music.

Akwasi Ampofo Agyei was versatile with the stylistic differences in Akan, as may easily be seen from any cursory examination of African and Western music and language. His music therefore incorporates extensive use of Akan proverbs to denote his distinctiveness. Many music composers use this style of writing to give audiences their preferred songs and some additional aesthetic and didactic values. Some of the stylistic devices, namely, consonance, alliteration, and personification, used in popular music such as the compositions of Ampofo Agyei are discussed briefly below. It must be noted that even though these terms are basic in literary text analysis, brief definitions have been provided to facilitate the point being made.

Consonance: It is the reoccurring of similar consonant sounds before and after different vowels. Cuddon (2013, p. 153) defines it as "The close repetition of identical consonant sounds before and after different vowels. For example: slip-slop; creakcroak; black-block" Examples found in Ampofo Agyei's song are:

17. Nte nsere dwene wo dec ho

'Do not laugh when you hear think about yours.'

In the above, there is the repletion of the vowel [-e]. 
Alliteration: Alliteration is the repetition of same sound either consonant or vowel in a verse or a sentence. It is a series of words that begin with the same letter of sound especially consonants as 'now or never', 'peace perfect peace.' Cuddon (2013, p. 22), states that "Alliteration is a figure of speech in which consonants, especially at the beginning of words or stressed syllables, are repeated. In Ampofo Agyei's song we meet a line like:
a. Monkata mo ani, montee.
b. Dua kontonkyi konkyi Eno na
c. Dompekwatirikwa see kwa

Close your eyes, then open

It is the crooked tree that A bare bone without any meat, spoils

The alliterations are found in $[\mathrm{m}]$ and $[\mathrm{k}]$ in the first and second lines. The alliteration is found in the bilabial nasal $[\mathrm{m}]$ in three out of the four words in (a).

Alliteration is a very old device in English, and it is common in verse generally and used occasionally in prose. Minkova (2006) adds that alliteration has a very vital role in poetry and prose. It creates a musical effect in the text that enhances the pleasure of reading a literary piece. Folk songs are poetic in nature and therefore conform to the ingredients of poetry; sound repetition therefore makes reading and recitation of the poems attractive and appealing and easier to learn and memorise.

Personification: Cuddon (2013, p. 529) pontificates that "Personification is the impersonation or embodiment of some quality or abstraction; the attribution of human qualities to inanimate objects". This is done by the use of certain action verbs and collocated nouns that relate to human beings; they have qualities. In this study, Ampofo Agyei attributes human nature to the following 
Ohia tu aberantec fo.

'Poverty advises the young man.' In the natural world advice is sourced from human beings and is targeted at other people. However, in this song, poverty [-human], is rendering a piece of advice to a young man.

\section{Proverbs}

Proverbs are terse sayings that embody general truths or principles and ways of life based on people's past experiences, philosophy, perception, ideology, socio-cultural concepts and worldview (see Agyekum, 2012, p. 11). We will see how Akans consider the usefulness of proverbs and witty sayings in their folksongs, especially highlife in this paper.

Oral literature scholars like Finnegan (2012), Yankah (1989), Okpewho (1992) and Agyekum (2016, 2005) have researched extensively into proverbs.Agyekum(2005,p.9) opines that "proverbs are interpretations of traditional wisdom based on the experiences and socio-political life of our elders." The use of proverbs is the acknowledged mark of one's communicative competence in Akan indigenous communication. If a speaker has the ability to use appropriate proverbs in right socio-cultural contexts, it depicts his/her communicative competence and versatility in the language and culture (see Agyekum, 2012; Yankah, 1989). For instance, Agyekum (2016 and 2005) noted that the oral artiste Alex Konadu uses a series of proverbs to depict his competence in the Akan language. The crafty ways by which the proverbs are aesthetically interwoven promote the song's communicative functions and further identify the artiste's creativity.

\section{The African concept of proverbs}

Scholars on African proverbs have identified the major functions of proverbs in their respective languages and cultures. We will look briefly at some of them. Agyekum (2005a, p. 10) posits that "In the Akan context, there are adages such as $\varepsilon b \varepsilon$ ne okasa mu abohemmaa, 'the proverb is the most precious stone 
of speech', etwa as\&m tia, 'it curtails matters', enka as\&m ho a, Enwie $d \varepsilon y \varepsilon$, "without it, a speech does not acquire its sweetness." The indigenous Akan perceives the proverb as an indispensable and aesthetic device of vitality in speech and as the salt of a language, without which the real taste of the "language dish" is not felt.

Proverbs are used as verbal strategies to stave off, or handle tense situations stemming from the face-to-face communication in African societies including Akan (see Agyekum, 2010; Yankah, 1989, 1991). Multiple proverbs in language concretise the value of language and culture and the expertise of speakers to handle face-threatening acts and depict the politeness systems of the respective cultures. If an Akan speaker is well versed in the culture and knows the background of his/her interactants, she/he can use the proper thematic proverbs as exemplified in this paper.

Hussein (2005, p. 61) discussed the use of African proverbs and the construction of masculinity and femininity, and examined how scholars of African literary works placed proverbs at a very higher level of communication. Some of the scholars are Ssetuba (2002), Oluwole (1997) and Finnegan (2012). Let us briefly explore their assertions on proverbs. Ssetuba (2002, p. 1) states that in Africa "The proverb is regarded as a noble genre of African oral tradition that enjoys the prestige of a custodian of a people's wisdom and philosophy of life." Hussein supports the indispensability of proverbs and its strong sync with philosophy and thought. Oluwole (1997, p. 100) records that in Africa, "proverbs are the analytic tools of thought, when thought is lost, it is proverbs that are used to search for it". We thus see proverbs as the prism and catalyst to the African worldview, thought and philosophy. Proverbs portray the wits, wisdom, intellect, environment and the sociocultural and political experiences of the African.

Finnegan (2012, p. 380), records African proverbs and opines that "In many African cultures a feeling for language, 
for imagery, and for the expression of abstract ideas through compressed and allusive phraseology comes out particularly clearly in proverbs." The Akans live by proverbs because sometimes the actions and inactions of most Akan adults emerge out of the proverbs that readily come into their minds.

\section{oba nyansafo wobu no be na wonka no asem by Ampofo Agyei}

The song text below was composed by the Kumapem Royals Guitar Band led by Mr. Akwasi Ampofo Agyei (alias, Dada Thick, Mr. AAA). It is on the record Gye $D a b i$ with the label Coconut (3) Colp 681. Format Vinyi LP Album. It was released in Ghana in 1988. The song under study is on Track B1.

(i). Dba nyansafoo y\&bu no be A wise person is spoken to in proverbs

Ao na yenka no assm $2 \mathrm{X}$

We do not speak to him in plain words

1. Oba nyansafo yebu no be A wise person is spoken to in proverbs

Na yenka no asem And not spoken to in plain words

Pba nyansafoo yebu no be A wise person is spoken to in proverbs

Dada se na yenka no as\&m Dada says we do not speak to him in plain words

Monkata mo ani, monte\&.

Mohunuu desbsn?

Close your eyes, then open

What did you see?

Aa! yeanhunu hwee

Aa! we did not see anything

Saa na yeanhunu biribiara

Na mose s\&n?

We really did not see anything 10

And what do you say 
Yeanhunu hwee

Dada e, yeanhunu biribiara

2. Ene ho, yennae a, yenso dae\&

Merekyer\& mede akosi s\&

3. Esum ba a, na yehunu bogya

4. Baabiara nni ho a

Wisie wo ho a, bogya nni ho

Dba nyansafoo yebu no be,

Ei na y\&nka no assm $2 \mathrm{X}$

(ii). Jba nyansafoo yebu no be

Na yenka no asem $2 \mathrm{X}$

5. Onipa mfon kwa

6. Ansa na onipa behwe yie no

$\mathrm{Na}$ \&firi de\& wahunu

7. Ohia tu aberante\& fo

8. Abrabo biara nni ho a

Aforosiane nni mu

9. Owuo de nkabom ba

10. Yaree nso sesa nnipa
We saw nothing

Dada, we did not see anything

That is it, without sleep

we do not dream

I am implying that 15

It is during darkness that we see glow-worm There is no place where

There is smoke without a glow-worm

A wise person is spoken

to in proverbs

Ei! we do not speak to

him in plain words 20

A wise person is spoken to in proverbs

We do not speak to him in plain words

A person does not grow lean for nothing

Before a person becomes cautious

It stems from what he has

experienced

25

Poverty advises the

youngman

There is no life

Without ups and downs

Death brings about unity

Sickness changes a

person

30

Legon Journal of the Humanities 31.1 (2020) 
11. Na se biribi anyewo a,

Wonhunu \&ho nyansa

Sba nyansafoo yebu no be

Ei na yonka no asem $2 \mathrm{X}$

(iii). 12. Ahunubipen nti na ma

Aboa aserewa regye ne ba agoro a,

Ey\& a na wayi n'ani ato nkyen

13. Oyirikayiri sbarima rebewu a,

Na ne yere suro no

14. Ereba a, na \&reyo

15. Assm suro abodwes\&

16. Dua kontonkyi konkyi \&no na

Ema yshunu odwumfor

Pba nyansafo yebu no be

Ei na yenka no asem $2 X$
If you are not afflicted by something You will not realise the lesson in it A wise person is spoken to in proverbs Ei! We do not speak to him in plain words It is because of experiences that is why 35

When the sparrow is playing with the child

It consistentl ycasts its eye to other directions

Oyirikayiri when a man is about to die

The wife is afraid of him

Approaching events cast their shadows 40 Issues are scared of beards

It is the crooked tree

That makes us notice the crafty carver A wise person is spoken to in proverbs Ei! We do not speak to him in plain words 45

(iv).17. Nte nsere dwene wo des ho Do not laugh when you hear think about yours 
18. Jpanin a ote $\varepsilon k a$ mpem aduosia ho An elder engulfed with GHS 6, 000 debts

Na ogyae kətu abofra fo

S\& əmmə ne bra yie no

Na sno shunuu ne bra bo a,

Anka ote mpem aduosia ka ho

Pba nyansafoo yebu no be

Na yenka no asem $2 \mathrm{X}$

(v). 19. Dompekwatirikwa see kwa

Tikya Wiase kae

Ades yi wowe a, snwe

Woto twene a, na w'ani di akyire

20. Hwempo aduro wo ho yi

Y\&mfa nsa kotodwe yare\&

Dba nyansafoo yebu no be

Na yenka no asem $5 \mathrm{X}$
And is ignoring it to advise a child

That he must put up a good life

If he had put up a decent life 50

Would he have been in GHS 6, 000 debt A wise person is spoken to in proverbs We do not speak to him in plain words

A bare bone without any meat, spoils Teacher Wiase said it 55

It is difficult to chew it

When you throw it away your eyes trace it

The medicine to heal nose wounds

Is not used to heal knee sickness

A wise person is spoken to in proverbs 60 We do not speak to him in plain words 


\section{Analysis of the proverbs in oba nyansafo wobu no be}

This section will look at the proverbs in the song and analyse them. The title of the song is itself a proverb, which is repeated several times in the song and used as a refrain to capture the song's main theme - wisdom. The song is situated within a proverbial context among the Akan where one of the contestants would ask the other to physically close his/her eyes. The prelude is found in lines 7-14 as follows:

Monkata mo ani, monte\&. Mohunuu desben?

Aa! yeanhunu hwee

Saa na y\&anhunu biribiara

Na mose s\&n?

Yeanhunu hwee

Dada e, yeanhunu biribiara Ene hə, yennae a, yenso dae\&
Close your eyes, then open What did you see?

Aa! we did not see anything We really did not see anything 10 And what do you say We saw nothing Dada, we did not see anything That is it, without sleep we do not dream

Let us now discuss the proverbs and their interpretations as they appear chronologically in the song text. The song is a piece of advice hammering on alertness and cautiousness in life (Agyekum, 2019).

1. Dba nyansafo yebu no be na yenka no asem 'A wise person is spoken to in proverbs but not in plain words.'

This is an Akan maxim that points to the role of proverbs in Akan traditional discourse. It asserts that a wise person is always talked to through proverbs, a mode of indirection, since he/she has the wisdom to analyse, whilst the foolish person is talked to bluntly for him/her to get the message. The other proverbs used as metalanguage to talk about proverbs are:

2. $(\mathrm{S} \varepsilon)$ yennae a, yenso daec

Legon Journal of the Humanities 31.1 (2020)
Without sleep we do not dream 
This is one of the signals that opens an Akan proverbial context; it is also a proverb. This implies that there is always a stimulus that calls for a response; we only have dreams during sleep. This is similar to the concept of day dreaming in English culture. Naturally, people sleep during the night when the atmosphere is calm; it then engineers a dream; it is abnormal then for Akans to be awake and still dream. The cause and reaction is further strengthened by the four adjacent proverbs.

3. (SE) esum ba a, na yehunu bogya.

'It is during darkness that we see glow-worm.'

4. Baabiara nni ho a wisise wo ho a, bogya nni ho

'There is no place where there is smoke without a glowworm.'

The glow-worm is only seen during the night, and usually found in the kitchen and thus associated with this specific smoke. The conditions are that there should be darkness. The two proverbs have two conditional clauses that begin the sentences marked by the $(s \varepsilon)$... a, 'if or when' conditional conjunction where the first part is optional and the second is obligatory.

5. Onipa mfon kwa

'A person does not grow lean for nothing.'

6. Ansa na onipa behwe yie no na efiri dee wahunu

'Before a person becomes cautious, it stems from what he has experienced.'

\section{Ohia tu aberantee fo}

'Poverty advises the young man.'

Proverbs 5-7 still support the stimulus and response principle. The first is that people do not grow lean out of nothing, there are always reasons; social, physical or psychological. 
In proverb 6, people are normally cautious based on some past unpleasant situations and predicaments. Those negative experiences guide them to move forward in life to avoid immersing themselves again into those nasty experiences.

(8). Abrabs biara nni ho a aforosiane nni mu

'There is no life without ups and downs,'

Every aspect of life is made up of aforosiane, made up of two verbs, foro, 'to climb' and siane, 'to descend'. When you are climbing you easily get tired, and it is very slow and takes time and that represents the negatives and hard times in life, but when you are descending, it is fast, and easy, and you do not pant and sweat. In life, even swiftness calls for cautiousness so that you do not fall and hurt yourself. All these proverbs are supported in each stanza by the core proverb, which is the refrain.

Sba nyansafo yebu no be

'A wise person is spoken to in proverbs.'

Proverb 7 seals the stimulus-response (cause and reaction) phenomenon discussed in proverbs 2-7, by saying that poverty advises the young man. Sometimes, some youth move about in life in haphazard manners but after going through hard times and poverty, they become careful and advise themselves. Other proverbs with the same themes are:

(9). Owuo de nkabom ba (10). Yaree nso sesa nnipa
'Death brings about unity.' Sickness changes a person

(11). Na se biribi anye wo a, wonhunu cho nyansa.

If you are not afflicted by something, you will not realise the lessons in it.' 
The above proverbs imply that most of the lessons and wisdom we acquire in life are stemmed from the negative experiences we go through. Negativity pre-empts positivity; positive life throughout without negatives is equal to less experience. If one sails through pluses in life and minuses set in while one is aged, it becomes difficult to find solutions.

In Akan, one of the benefits of funerals is that it brings about unity; we conglomerate at single places as one unit to perform grand funerals and those are the periods to settle conflicts. As a collectivist society we contribute in donations or share the outstanding debts so that the core family is not financially overburdened. We pray that we will not fall sick as the proverb in (10) states, sickness can change the status quo of people. The implied admonition is that we should not be complacent in life for anything at all can happen to us including sickness. The predicaments and the realities of life are portrayed through the parallel proverbs below. The proverbs also exemplify the theme on cautiousness and experience.

(12). Ahunubipen nti na aboa aserewa regye ne ba agoro a, na wayi n'ani ato nkyen

'It is because of experiences that is why when the sparrow is playing with the child, it consistently casts its eyes to other directions.'

The first word ahunubipen is a compound made up of $a$-, 'has' + hunu, 'see', $+b i$, 'some' $+p \varepsilon n$, 'before'. The meaning is taken from the polysemy and the compounds of the hunu, perceptive verb (see Agyekum, 2005b). The sparrow bird has ever been afflicted by man because it was not very alert. Having gone through this, now even when it is cuddling and playing with its child, it is always alert and aware that there could be a mishap, so it looks round. A wise person should learn to avoid being taken aback. 
(13) Oyirikayiri sbarima rebewu a, na ne yere suro no Oyirikayiri when a man is about to die, the wife is afraid of him.'

(14) Ereba a, na عreys

15) Asem suro abodwese
'Approaching events cast their shadows.'

'Issues are scared of beards.'

Proverbs (13)-(15) indicate that no matter how close people are, there are times one can be afraid of a relative and this is a natural thing people should be aware of and be alert. It is because of sudden death that the sparrow is alert. Similarly, because of death, a wife could be afraid of the dying dear husband despite the love. Another fearful thing is a beard; Akans naturally do not grow beards, and it is very uncommon to see chiefs with beards and bushy hair. They think that people who have bushy beards are not remorseful; they have metaphorically covered their faces with hair and cannot see clearly what people are going through. If there is an ensuing problem and a bearded person arrives, the case could be settled easily because of the power of the beard.

On the notion of wisdom, the composer states that if one is wise, one is crafty and can create beautiful things out of nothing, hence the proverb below.

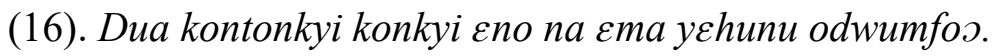

'It is the crooked tree that makes us notice the crafty carver.'

Artisans including carvers, sculptors, and carpenters are not normally judged by the end product of their work alone but also by the type of raw material they use. To carve out something appealing and gratifying from an object that could have been discarded, marks the traits of a perfect artisan. 
(17). Nte nsere dwene wo dee ho.

'Do not laugh when you hear, think about yours.'

Towards the conclusion of the song, Ampofo Agyei remarked that wise people should be careful that anything at all can happen to anybody at anytime; therefore, if somebody is in trouble we should rather console and sympathise with him/her. The advice is that you cannot predict what can befall you in the future. The composer intersperses the proverbs with how people should work hard and live decently so that in future they can use their life experiences as a model to advise the youth.

18. Dpanin a ste $\varepsilon k a$ mpem aduosia ho 'An elder engulfed with GHф6,000 debt

Na ogyae kotu abofra fo

Se эmmo ne bra yie no

Na sno shunuu ne bra bo a,

Anka ste mpem aduosia ka ho?
And is ignoring it to advise a child

That he must put up a good life

If he had put up a decent life 50

Would he have been in GHф6,000 debt.?

Proverb 18 is called $A s \varepsilon m-s \varepsilon-b \varepsilon$, a narrative proverb, and such proverbs are normally longer. The composer is saying that if you have not handled your life well and you are indebted during your adult life you cannot advise a younger person to put up a decent and financially sound life. The youth may not listen, because they may think that you have nothing better to give as a model. We as analysts think that the other side of the coin can work, the older person can advise them on the type of lifestyle he/she embarked on resulting in the precarious financial status he/she finds himself/herself. It is therefore a good lesson for the 
youth to avoid such a negative behavioural life track.

The composer then proceeds to talk about enigmatic situations using the metaphor of a bare bone. The Akans, as part of their tradition, chew bones when they are eating meat. If you encounter a bare bone without some meat on it but has some marrow in it; it is a problem even though in the end it will be thrown away as seen in proverb 19.

(19). Dompekwatirikwa see kwa

'A bare bone without any meat.'

What makes the bare bone more painful is that it is difficult to chew yet when you throw it away your eyes follow and crave it indicating that you should have tried a little harder. This depicts that in real life situations, there is always a conundrum and it takes wisdom to unravel the knots. This is a lesson for the wise person to grapple with. The semantic parallel is in proverb 20 which proposes that each situation should be handled on its own merit.

(20). Hwempo aduro wo ho yi yemfa nsa kotodwe yaree.

'The medicine for nose wounds is not used to heal knee sickness.'

A wise person should understand that each ailment calls for its own medicine. If you mix up things you will not get a better result. This metaphor implies that in life, each situation calls for appropriate solutions and management, hence omnibus solutions are not ideal.

\section{Themes of the Song}

The major theme of the song is advice, using proverbs instead of plain words as captured in the refrain. 
Jba nyansafoo yebu no be Ao na yenka no asem 2X
A wise person is spoken to in proverbs

We do not speak to him in plain words

This is foregrounded first as the title of the song, the prologue and as the epilogue. It is used as the refrain in all the five verses of the song as a foregrounding strategy. There are supporting themes on alertness, cautiousness, life changes, uncertainties, learning from experiences, positivity emerges from negativity, etc. All these themes are channelled through existing proverbs and crafted into a song that depicts the artiste's creativity.

\section{Conclusion}

The paper has noted that stylistic devices especially proverbs are indispensable in Akan oratory and form part of speakers' communicative competence. Akan expert ethnomusicologists and renowned musicians spice their songs with proverbs that enrich the stylistic nature of the language. Using proverbs as forms of indirection, highlife musicians are able to comment on very delicate issues without incurring the displeasure of their addressees. The use of proverbs in music helps the listeners to understand the cultural beliefs, perception, worldview, wisdom and philosophy of life, oral traditions and social structures of the Akan. In this paper, we have seen that the Akans are highly linked with their proverbs and this symbiotic relation is manifested in their behaviour and social ties with others. We further noted that "proverbs are the analytic tools of thought, when thought is lost; it is proverbs that are used to search for it". We also made the point that proverbs are used as expressions of abstract ideas and emotions.

This paper has shown that music can serve as a reliable storage mode for the documentation of some of our proverbs. The paper averred that ethnomusicologists do not only work on 
the form, description, structure and analysis of the music, but also study the people's music from anthropological standpoints. The various proverbs that highlight Akan language and culture were appropriately crafted into the song. The paper has further proved that one of the major tools and guidelines for advice among the Akans is through their folksongs especially highlife imbued with proverbs.

The current generation of Akan highlife musicians do not employ proverbs as efficiently as we have seen in the lyrics of Ampofo Agyei and his compatriots. The reason is that they are not very versatile and communicatively competent in their language and culture. If this trend continues Akan ethnomusicology will suffer. To keep the rich oratory in music through the use of proverbs, the current generation should make conscious efforts to master the Akan language by reading some books on Akan literature and customs and institution and listen to the highlife of the 1960s-1990s. They should also try to avoid the current propensity to use vulgar language in musical compositions. The current generation of composers are indeed very creative in rhythm and rhymes; therefore, with good background in the Akan language and its communicative protocols they can excel. 


\section{References}

Agawu, K.V. (2016). The African imagination in music: Oxford: University Press.

Agyekum, K. (2019). The ethnopragmatics of Akan advice. Pragmatics 29 (3): 309-331.

Agyekum, K., Amuah, J. A. and Wuaku, H. M (2019). The role of Music in Ghanaian political communication. In S. Gyasi Obeng and E. Debrah (Eds). Ghanaian Politics and Political Communication. pp. 233-256 London: Rowman and Littlefield International Ltd.

Agyekum, K. (2016). The sociocultural concept of ohia, 'poverty' in Akan: Konadu's song Enee meks na maba.' South African Journal of African Languages 36(2): 163-171.

Agyekum, K. (2013). Introduction to literature. $3^{\text {rd }}$ Edition Accra: Adwinsa Publications.

Agyekum, K. (2012). Akan proverbs and aphorisms about marriage. Research Review NS 27(2):1-24.

Agyekum, K. (2010). Language, gender and power. Issues in Intercultural Communication 3(2): 165-183.

Agyekum, Kofi (2005a). An Akan oral artist: The use of proverbs in the lyrics of Kwabena Konadu. Research Review. 21(1):1-17. Institute of African Studies Legon.

Agyekum, Kofi (2005b). Polysemy and metaphorical extensions of hunu 'vision' verb of perception in Akan. In M. E. Kropp Dakubu and E. K. Osam (Eds.) Studies in the languages of the Volta Basin Vol 32. Proceedings of the annual colloquium of the Trondheim Linguistics Project 18-20 Jan. 2005 pp. 147-162

Amoah-Ramey, N. A. (2018). Female Highlife Performers in Ghana: Expression, Resistance, and Advocacy. Maryland: Rowman \& Littlefield Publishers.

Blacking, J. (1995). Venda children's songs: A study in ethnomusicological analysis. Chicago: University of Chicago Press edition.

Blum, S. (1992). Analysis of musical style in ethnomusicology: An Introduction. New York, London: W.W Norton and Company.

Bright W. (1963). Language and music: Areas for cooperation. Ethnomusicology 7(1): 26-32.

Busse, B., \& McIntyre, D. (2010). Language, literature and stylistics. In D. McIntyre, \& B. Busse (Eds.), Language and style (pp. 3-14). Basingstoke: Palgrave Macmillan UK.

Chernoff, M. J. (1979). African rhythm and African sensibility. Aesthetic and social action in African musical idioms. Chicago and London: University of Chicago Press.

Collins, E.J. (1989). The early history of West African highlife music. Popular Music, 8 (3) African Music 8(3): 221-230.

Collins, E.J. (2006). African guitarism: One hundred years of West African highlife. Legon Journal of the Humanities, 17(17): 173-196.

Legon Journal of the Humanities 31.1 (2020) 
Coplan, D. (1985). In Township tonight! South Africa's Black City music and theatre. London \& New York.

Cuddon, J. A. (2013). A dictionary of literary terms and literary theory. West Sussex: Wiley Blackwell.

Fairclough, N. (1989). Language and power. London: Longman Group Ltd. Finnegan, R. (2012). Oral literature in Africa. $2^{\text {nd }}$ Edition. Cambridge: Open Book Publishers.

Hussein, J.W. (2005). The social and ethno-cultural construction of masculinity and femininity in African proverbs. African Study Monographs, 26(2): 59-87.

Irvine J. T. (1989). When talk isn't cheap. Language and political economy. American Ethnologist 16: 248-267.

Irvine, J. T., and Gal, S. (2000). Language ideology and linguistic differentiation. In Paul V. Kroskrity (Ed.) Regimes of language; ideologies, polities, and identities. (pp. 35-84). Santa Fe, NM: School of American Research, Press.

Kroskrity, P. V. (2006). Language ideologies. In Duranti A. (Ed.), A companion to linguistic anthropology. pp 496-517. Malden: Blackwell Publishers.

Leech, G. N. (1969). A Linguistic guide to English poetry. London: Longman.

Merriam, A.P. (1964). The Anthropology of music. Illinois: Northwestern University Press.

Minkova, D. (2006). ґAlliteration and sound change in Early English. Cambridge University Press.

Nettl, B. (2005). The study of ethnomusicology: Thirty-one Issues and Concepts. Urbana/Chicago: University of Illinois Press.

Nketia, J.H.K. (2005). Ethnomusicology and African music: Modes of inquiry and interpretation. Collected Papers Vol.1. Accra: Afram Publications.

Nketia, J.H.K. (1964). Traditional and contemporary idioms of African music. Journal of the International Folk Music Council, 16: 34-37

Nketia, J.H.K (1959). Changing traditions of folk music in Ghana. Journal of the International Folk Music Council, 11: 31-3.

Nketia, J.H.K. (1957). Modern trends in Ghana music. African Music: Journal of the International Library of African Music, 1(4):13-17

Oluwole, S. B. (1997). Culture, gender, and development theories in Africa. Africa Development, 22 (1): 95-121.

Okpewho, I (1992), African Oral Literature: Backgrounds, Character, and Community. Bloomington: Indiana University Press.

Rumsey, A. (1990). Wording, meaning and linguistic ideology. American Anthropologist 92(2):346-361.

Ssetuba, I. (2002). The hold of patriarchy: An appraisal of the Ganda proverb in the light of modern gender relations. A paper for Cairo Gender Symposium, April 7-10, 2002. Cairo.

Legon Journal of the Humanities 31.1 (2020)

Page $\mid 143$ 
Silverstein, M. (1998). The uses and utility of ideology. A commentary. In Schieffelin, B. B., Woolard, K. A., Kroskrity, P. V. (Eds.), Language ideologies: Practice and theory. New York. Oxford University Press. pp 122-145.

Verschueren, J. (1999). Understanding pragmatics. London: Arnold Publishers.

(1989). Proverbs: The aesthetics of traditional communication. Research in African Literature 20 (3):325-346.

Wales, K. (2014). A dictionary of stylistics. London: Routledge.

Waterman, A. S. (1984). Identity formation: Discovery or creation? Journal of Early Adolescence, 4, 329-341.

Yankah, K. (1991). 'Orality in Akan Society'. Discourse and Society. 2(1):4764. London, Newsbury Park: Sage.

Yankah, K. (1997). Nana Ampadu, the sung-tale metaphor, and protest discourse in contemporary Ghana. In Adjaye J. K. and Adrianne R. Andrews (Eds.) Language, rhythm, and sound: Black popular cultures into the twenty-first century. pp. 54-73. Pittsburgh, Penn: University of Pittsburgh Press. 